\title{
Characterization of hairs and pappi from Cynara cardunculus capitula and their suitability for paper production
}

\author{
Jorge Gominho ${ }^{a, *}$, Ana Lourenço ${ }^{a}$, Maria Curt $^{b}$, \\ Jesús Fernández ${ }^{b}$, Helena Pereira ${ }^{a}$ \\ a Centro de Estudos Florestais, Instituto Superior de Agronomia, Universidade Técnica de Lisboa, \\ Tapada da Ajuda, 1349-017 Lisboa, Portugal \\ b Departamento de Produccion Vegetal, Universidad Politecnica de Madrid, Botanica y Proteccion Vegetal, \\ Av. Complutense s/n 28040-Madrid, Spain
}

\section{A R T I C L E I N F O}

\section{Article history:}

Received 10 March 2008

Received in revised form

11 April 2008

Accepted 20 April 2008

\section{Keywords:}

Cynara cardunculus L.

Hairs

Pappi

Chemical composition

Kraft pulp

Anatomy

\begin{abstract}
A B S T R A C T
The capitula of Cynara cardunculus contain hairs and pappi representing $7 \%$ of the total plant biomass. These low density biomass components could be mechanically separated without apparent losses using a whole-plant processing prototype. Hairs and pappi are filamentous structures made up of longitudinally aligned fibre cells, without intercellular voids or pitting, with the following dimensions regarding length, width and wall thickness: $1.35 \mathrm{~mm}, 19.8$, and $4.8 \mu \mathrm{m}$ for hairs and $1.78 \mathrm{~mm}, 10.4$, and $2.9 \mu \mathrm{m}$ for pappi. Chemically hairs and pappi have low content of ash (1.9\% and $1.1 \%$, respectively), extractives $(5.4 \%$ and $6.0 \%)$ and lignin (10.6\% and $17.8 \%$ ), and high content of holocellulose (77.5\% and $72.8 \%$ ) and $\alpha$-cellulose $(55.2 \%$ and $46.8 \%)$.

Pulps could be produced using a conventional kraft process with high yields and low residual lignin, e.g. $63 \%$ at Kappa 7 for hairs and $48 \%$ at Kappa 11 for pappi, low coarseness values $\left(0.04\right.$ and $0.03 \mathrm{mg} \mathrm{m}^{-1}$ ) and adequate pulp properties for paper ( 40 and $42 \mathrm{~N} \mathrm{mg}^{-1}$ tensile index; 3.6 and $3.4 \mathrm{kPa} \mathrm{m}^{2} \mathrm{~g}^{-1}$ burst index in unrefined pulps of hairs and pappi, respectively). The results also indicated that there is scope for improving pulp quality by optimising pulping conditions to this type of new raw materials. The differences between hairs and pappi may also be further exploited namely the lower lignin content of hairs and the higher slenderness and wall thickness of pappi fibres.

The utilization of hairs and pappi may strengthen the differentiated use of biomass fractions of the Cynara plant and its potential as a bioenergy crop.
\end{abstract}

(c) 2008 Elsevier B.V. All rights reserved.

\section{Introduction}

The thistle Cynara cardunculus L. is one promising perennial crop that can be grown in hot and dry Mediterranean climates with high biomass productivities (Fernández and Manzanares, 1990; Gominho et al., 2001). It is an herbaceous species of the Asteraceae family (Compositae) that grows as a wild plant in the Mediterranean region (Franco, 1984). In the context of energy crops, it is generally known as Cynara. This thistle has been the object of several R\&D programs with EU support to evaluate its aptitude for biomass production and use (Fernández, 1990, 1993a, b, 1998). At present the European project ECAS (Energy Crops in the Atlantic Space) studies the large scale cultivation of this

\footnotetext{
* Corresponding author. Tel.: +351 213634662; fax: +351 213645000.

E-mail address: jgominho@isa.utl.pt (J. Gominho). 
(a)

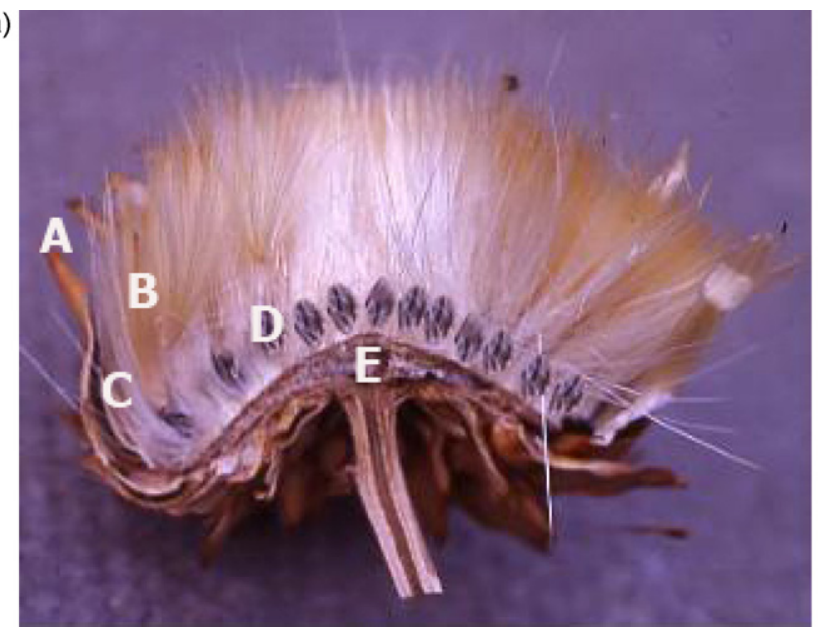

(b)

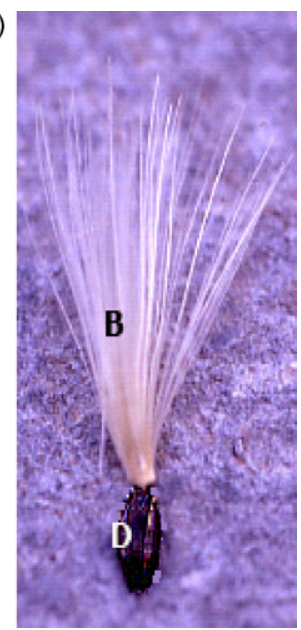

Fig. 1 - Longitudinal cut of the Cynara cardunculus L. head at harvest time (a). Macroscopic view of pappus link to achene (b). Legend: (A) bract; (B) pappus; (C) hairs; (D) achene (seed); (E) receptacle.

crop and approximately 400 ha were installed in Portugal (http://www.isa.utl.pt/def/interreg/).

The biomass can be used for multiple purposes e.g. energy from biomass combustion (González et al., 2004; Fernández et al., 2006), biodiesel from the oil in the seeds (BenjellounMlayah et al., 1997; Fernández and Curt, 2004; Fernández et al., 2006), forage, enzymatic source for the milk coagulation in traditional cheese making (Pires et al., 1994) or as fibre supply for pulp and paper industries (Villar et al., 1999; Antunes et al., 2000; Gominho and Pereira, 2000, 2006; Gominho et al., 2001).

The average annual production varies from 15 to 20 tons/ha depending on soil and rainfall, with 11-15\% moisture content at harvest, and with the following biomass partitioning: $40 \%$ stalks, 25\% leaves and 35\% capitula (Fernández, 1992, 1993a,b; Dalianis et al., 1996). Capitula, commonly known as 'head', are the basic type of inflorescence and rather complex in structure (Fig. 1). Each plant may develop many heads, organized in corymb-like groups. The heads are ovate to globular, 33-75 $\mathrm{mm} \times 32-95 \mathrm{~mm}$ in size, and contain numerous tubular flowers ('florets'), about $5 \mathrm{~cm}$ long, with a dark or pale lilac or bluish colour. The florets rise from a flattened surface, the 'receptacle', surrounded by bracts. Inside the capitulum, and subtending the florets, there are many bristles (interflower bracts) like stiff white hairs. At maturity, Cynara heads contain numerous fruits attached to the receptacle. The fruit is an achene (one-seed dry fruit), the same as in the sunflower, but has a crown of plumose filaments known as 'pappi' (a structure for fruit dispersal) (Fig. 1).

Several fractions can therefore be distinguished in the mature head of Cynara: receptacle, bracts, pappi, hairs (bristles) and fruits (achenes). Their mass proportion, or head biomass partitioning, varies with the plant development, namely the head size. A mature head may weight from 10 to $120 \mathrm{~g}$, distributed on average as follows: the receptacle represents $18 \%$, the bracts $25 \%$, the fruits $32 \%$ and the light material (hairs, pappi, and remains of corolla, stamens and styles) $25 \%$ (Fernández and Curt, 2005), of which hairs and pappi represent the main fraction (80\%). Similar values were recorded by Piscioneri et al. (2000).
The fruits, or 'seeds' as they are usually called, contain about $25 \%$ of oil that can be transesterified with methanol or ethanol to produce biofuels (Benjelloun-Mlayah et al., 1997; Fernández and Curt, 2004). The mechanical separation of seeds from the capitula originates a by-product composed by bracts, hairs and pappi. The hairs and pappi are very light components that can be gravimetrically separated from the other solids. These two fractions are rich in fibres and can be envisaged as a raw material for fibre or pulp products.

The evaluation of the Cynara thistle as an energy and industry crop requires assessment of utilization alternatives of all plant components. The objective is to have a full and value-optimized use of the Cynara plant with differentiated conversion processes for the various biomass components according to their aptitude. This was the rationale behind our study and we applied it to the fraction of hairs and pappi, which make up about 7\% of the whole plant, that have not been characterized so far. We analyzed these components as a potential fibre source, by making their anatomical and chemical evaluation and assessing their potential as a raw material for pulp production.

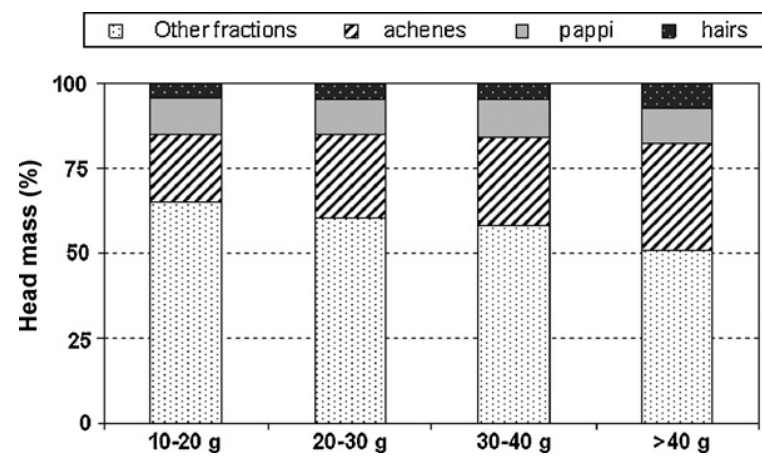

Fig. 2 - Biomass partitioning (\%) of the heads of Cynara cardunculus $L$. as a function of the head weight. 


\section{Material and methods}

\subsection{Material separation}

The plant material used for this work came from C. cardunculus L. field trials carried out by the Escuela Técnica Superior de Ingenieros Agrónomos (Universidad Politecnica de Madrid, Spain). The studies were conducted with hairs and pappi from naturally air-dried capitula of $C$. cardunculus previously subjected to mechanical separation in a specially designed prototype as follows. The machine was fed with whole heads which were crushed by a set of counter-rolling cylinders. The achenes were removed by gravimetric separation on vibrating trays endowed with screens and the light material was driven by an air flow to a separation cyclone where hairs and pappi were separated from the other light material. The hairs were separated by sedimentation and pappi were gathered from a screen by a sweeping device. The prototype for separation of hairs and pappi was coupled to existing equipment for the unrolling of whole-plant cylindrical bales and separation of capitula. A mass balance for the mechanical separation process was calculated using the mass of the products obtained in relation to the initial mass of feed material.

The equilibrium moisture of the plant material used for this work was $8 \%$ for the hairs fraction and $2 \%$ for the pappi. The partitioning of Cynara capitula into the fractions of receptacle and bracts, achenes, hairs and pappi was also made by hand in 40 randomly selected heads that were collected in the field at maturity.

\subsection{Anatomy and biometry}

The structure and anatomy of hairs, pappi and of handsheets produced with their unbleached kraft pulps were studied by electron scanning microscopy (SEM) and optical microscopy.

For the optical observations, hairs and pappi were cut in transverse sections after inclusion in polyethylene glycol (DP 2000) with $0.17 \mu \mathrm{m}$ thickness with a Reichert sliding microtome, stained with chrysodine and astral blue and mounted in Euparal. The biometry of cells was measured using a semiautomatic system (Leitz-ASM 68K), in dissociated elements obtained by maceration using acetic acid and hydrogen peroxide (1:1) and astral blue staining. Fibre length was measured in 40 unbroken fibres per sample, and total fibre width and lumen width were measured at mid-length. Cell wall thickness was calculated as (fibre width-lumen width)/2. The length of fibre elements in the pulps was measured in 200 fibres. For SEM observations the samples were gold coated and observed using different magnifications.

\subsection{Chemical analysis}

The chemical analysis was performed according to TAPPI standard methods to determine ash, extractives, lignin and polysaccharides. The inorganic material was determined gravimetrically after total combustion at $500^{\circ} \mathrm{C}$ for $6 \mathrm{~h}$ in a muffle (T 211 om-02). The extractives content was determined using in succession three solvents with different polarities (dichloromethane, ethanol and water) with an adapted Soxtec extraction system (modified from $\mathrm{T} 12$ os-75). The acid insoluble (Klason) lignin and the acid soluble lignin were determined according to T 222 om-02 and UM T 250, and monosaccharides by GC after derivatisation to alditol-acetates ( $T 249 \mathrm{~cm}-00$ ). The carbohydrate complex was also quantified as holocellulose and $\alpha$-cellulose. Holocellulose content was determined in extractive-free material by the chlorite method with $240 \mathrm{~min}$. reaction time (Browning, 1967) and $\alpha$-cellulose in extractivefree and lignin-free holocellulose (method described in Rowell, 2005). The hemicelluloses fraction was calculated by difference between holocellulose and $\alpha$-cellulose content.

\subsection{Pulping and pulp properties}

Kraft pulps were made with pappi, hairs and a mixture (1:1 in weight) of hairs and pappi, in $100 \mathrm{~mL}$ stainless steel autoclaves rotated in an oil bath with controlled temperature. The process variables were: liquor-to-solid ratio 8:1; sulphidity $30 \%$; alkali active (as $\mathrm{Na}_{2} \mathrm{O}$ ) $15 \%, 20 \%$ and $25 \%$; temperature $170{ }^{\circ} \mathrm{C}$, during $2 \mathrm{~h}$. At the end of pulping, the autoclaves were immersed in ice and the pulps were thoroughly washed with hot water and air-dried.

Total yields were calculated (oven dried until constant weight at $105^{\circ} \mathrm{C}$ ) and the pulps characterized. Kappa number was measured in accordance with TAPPI 236 os-76 in an automatic titration equipment (TitraLab), and viscosity according to SCAN-CM 15:88. The degree of polymerization

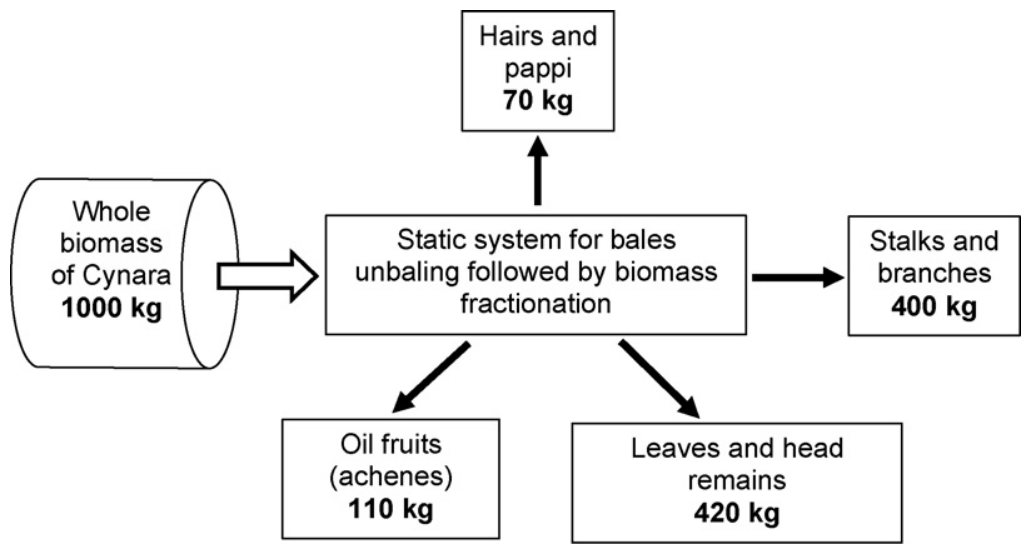

Fig. 3 - Fractionation of Cynara cardunculus L. biomass harvested as whole. 
(a)

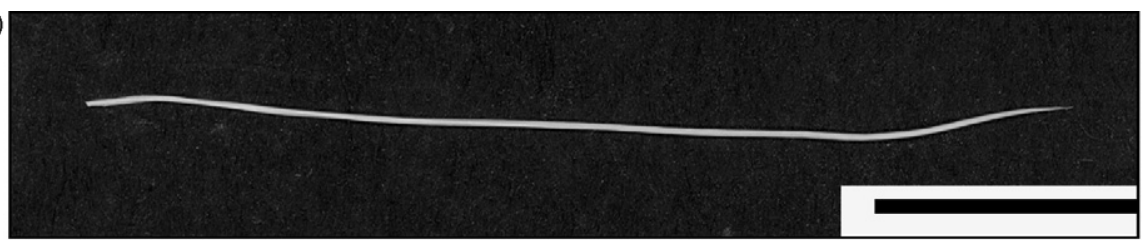

(b)

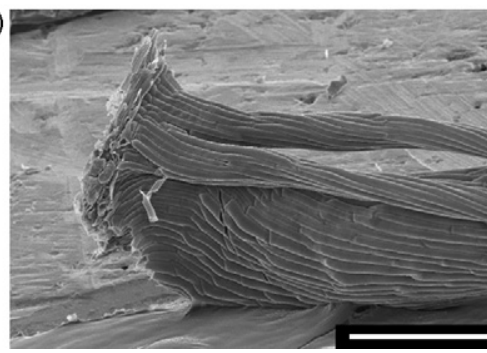

(c)

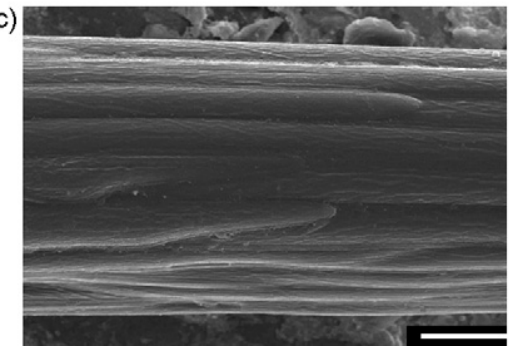

(d)

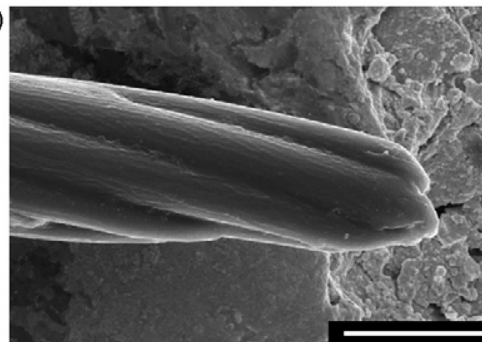

Fig. 4 - General aspect of a hair (a). SEM images showing details of the hair: base (b), middle (c) and top (d). ( - ) Scale bar; (a) $1 \mathrm{~cm}$; (b) $300 \mu \mathrm{m}$; (c and d) $30 \mu \mathrm{m}$.

was calculated from viscosity ( $\mathrm{n})$ data using $\mathrm{DP}^{0.85}=1.1^{*}[\mathrm{n}]$. The content of hexeneuronic acid (HexA) groups was obtained according to Chai et al. (2001): the pulps were hydrolyzed in a chloride-sodium acetate solution and the HexA groups were determined according to the equation: $C_{\text {HexA }}=0.287 \times\left(\left(A_{260}-1.2 \times A_{290}\right) \times V / w\right)$, where, $A$ is the absorbance at 260 and $290 \mathrm{~nm}, \mathrm{~V}$ is the volume of the hydrolysis solution $(\mathrm{mL}) ; w$ is the sample weight $(\mathrm{g})$. Handsheets were produced according to Tappi standards (T 205 os-71) and physical-proprieties determined: bulk ( $\mathrm{T} 426$ os-46), tensile index, stretch (T 494 om-01) and burst index (T 403 om-91). Paper colour was measured with a Minolta CM-3630 (d/ $\left.0^{\circ}\right)$ spectrometer using the $L^{*} a^{*} b^{*}$ parameters from the CIE scale, as well as brightness (T 525 om-92). The biometric properties of pulps, i.e. fibre length, width and coarseness were evaluated in a MORFI LB01-TECHPAP equipment.

\section{Results and discussion}

\subsection{Head partitioning into hairs and pappi}

The biomass partitioning of the Cynara heads into hairs and pappi was determined by randomized head sampling followed by hand fractionation. The weight of Cynara heads sampled at harvest time ranged from 13.1 to $110.0 \mathrm{~g}$ showing variability in the range already reported by Fernández and Curt (2005). Partitioning is given in Fig. 2 as a function of head size. In medium sized heads (30-40 g), hairs and pappi represented, respectively, $4.8 \%$ and $11.2 \%$ of the head total weight. The mass proportion of pappi was relatively constant while the proportion of achenes and hairs increased with head weight and the fraction made up by the receptacle and bracts decreased.

\subsection{Mechanical separation}

Tests carried out with the biomass fractionating prototype allowed the development of a whole-biomass processing line for the separation of the different fractions of Cynara biomass at operating scale. The system elements were the following: (i) unit for the unrolling of round bales of Cynara whole biomass; (ii) head crushing unit; (iii) separation unit of stalks and branches; (iv) unit for aspiration and sedimentation of hairs and pappi; and (v) threshing unit to separate the achenes from other plant material (leaves, head remains). The system worked without problems and the fractions were recovered apparently with adequate homogeneity and without major losses. A diagram of this separation system, with indication (a)

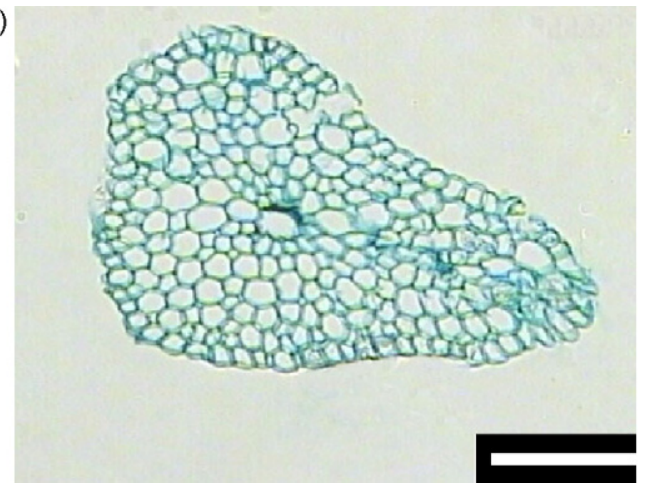

(b)

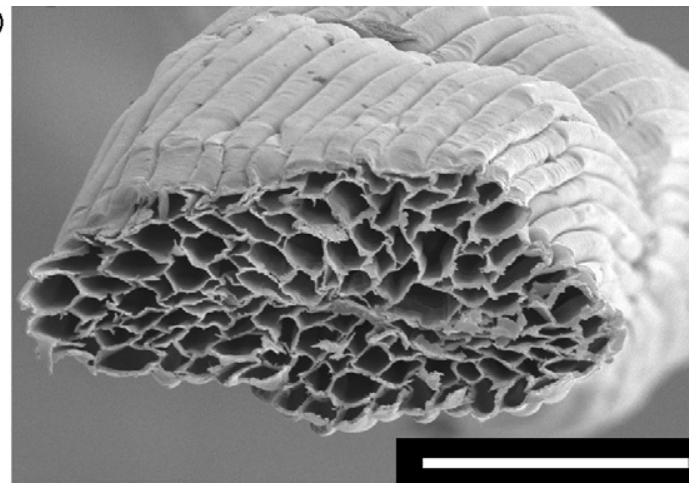

Fig. 5 - Transverse sections of a C. cardunculus L. hair observed in optical microscopy with $125 \times$ magnification (a) and in scanning electron microscopy (SEM) (b). (-) Scale bar, (a and b) $100 \mu \mathrm{m}$. 
Table 1 - Length and cross-sectional dimensions for the cells present in hairs and pappi from the capitula of Cynara cardunculus L.

\begin{tabular}{|c|c|c|c|c|}
\hline & Length (mm) & Width $(\mu \mathrm{m})$ & Lumen width $(\mu \mathrm{m})$ & Wall thickness $(\mu \mathrm{m})$ \\
\hline \multicolumn{5}{|l|}{ Hairs } \\
\hline Mean & 1.35 & 19.8 & 10.5 & 4.8 \\
\hline Standard deviation & 0.42 & 3.6 & 3.4 & 1.3 \\
\hline Maximum & 2.80 & 31.9 & 16.7 & 8.0 \\
\hline Minimum & 0.81 & 11.4 & 4.8 & 2.5 \\
\hline \multicolumn{5}{|l|}{ Pappi } \\
\hline Mean & 1.78 & 10.4 & 4.6 & 2.9 \\
\hline Standard deviation & 1.13 & 1.4 & 1.5 & 0.6 \\
\hline Maximum & 5.40 & 13.1 & 7.7 & 4.8 \\
\hline Minimum & 0.66 & 7.9 & 1.8 & 2.1 \\
\hline
\end{tabular}

of the obtained average proportion of each biomass fraction, is shown in Fig. 3. The fraction of hairs and pappi represented $7 \%$ of the whole biomass feed, a value that fits well with the obtained biomass partitioning of the capitula and the average head proportion in the plant (Fernández, 1992, 1993a,b; Dalianis et al., 1996).

The collection of these fractions is very advantageous for the Cynara raw material handling, namely during shredding and transport, and it is a requirement when separating seeds for oil extraction, because their very low bulk density and tendency to fly away may cause processing and environmental difficulties and be a source of biomass losses.

It is thus feasible to envisage a commercial separation of this light material of the Cynara plant and to process it independently, either in a composite sample or fractionated into hairs and pappi.

\subsection{Anatomy and biometry}

The hairs (interflower bracts) of $C$. cardunculus are linked to the receptacle (Fig. 1a). One hair has a filamentous structure (Fig. 4) with an average $40 \mathrm{~mm}$ length and an approximate circular cross-section with a mean diameter of about $0.1-0.2 \mathrm{~mm}$ (Fig. 5). It is constituted by several fibre cells that are oriented longitudinally along the hair with a tightly parallel arrangement (Fig. $4 \mathrm{~b}$ and c). The cells show no communication structures, i.e. pits, and they end with a smooth pin-like form (Fig. 4d). In transverse sections it can be observed that the cells are arranged regularly around a central shaft without intercellular voids (Fig. $5 \mathrm{a}$ and $\mathrm{b}$ ). The average dimensions of dissociated cells are $1.35 \mathrm{~mm}$ in length, $19.8 \mu \mathrm{m}$ in width and $4.8 \mu \mathrm{m}$ in wall thickness (Table 1).

The pappus group numerous plumose filaments (Fig. 6a and b) with $25-40 \mathrm{~mm}$ of length that are linked individually to a crown on the top of one achene (Fig. 1b). In cross-section each pappus shows a flattened form with crossdimensions of about $0.1-0.3$ and $0.05-0.1 \mathrm{~mm}$ and with an approximate straight and a more convex surface (Fig. 7). The pappus is constituted by parallel aligned cells that are oriented longitudinally without intercellular voids. The cells are fibrous, without pits, and in cross-section have a rather regular arrangement in layers parallel to the surface. The plumes are individual cells that partially separate at the surface of the pappus (Fig. $6 \mathrm{~d}$ and e). The pappus cells have an average length of $1.78 \mathrm{~mm}$, and the cross-sectional dimensions of dis- sociated cells are 10.4, 4.6 and $2.9 \mu \mathrm{m}$, respectively, for width, wall thickness and lumen width (Table 1).

There are no references in literature regarding the anatomy and the cell biometry in Cynara capitula or in other species. The majority of biometric studies made with Cynara were related to cells from stalks where the fibres varied in length between 0.9 and $1.3 \mathrm{~mm}$, in total width, 15.0-21.0 and 3.2-9.1 $\mu \mathrm{m}$ in lumen width (Quilhó et al., 2004; Gominho et al., 2001).

Regarding their pulping aptitude, the cells of pappi and hairs from Cynara are long and thin walled with an adequate biometry as paper fibres. They compare to other non-wood fibres used in the pulp industry, i.e. in length (kenaf fibres $1.3 \mathrm{~mm}$, reed $1.2 \mathrm{~mm}$, switchgrass $1.1 \mathrm{~mm}$, miscanthus $1.0 \mathrm{~mm}$, cotton stalks $0.8 \mathrm{~mm}$ and wheat straw $0.7 \mathrm{~mm}$ ) and in wall thickness $(4.1-5.0 \mu \mathrm{m}$ for the various crops) (Shatalov et al., 2001; Ververis et al., 2004; Deniz et al., 2004). They are shorter than bamboo $(2.8 \mathrm{~mm})$, cotton or hemp $(2.0 \mathrm{~mm})$ (Karlsson, 2006). Hairs and pappi fibres also compare favourably with $E$. globulus wood, a valued source of sort-fibres

Table 2 - Chemical composition (\% of oven dry mass) of hairs and pappi biomass from capitula of Cynara cardunculus $\mathrm{L}$.

\begin{tabular}{lcc}
\hline & Hairs & Pappi \\
\hline Ash & 1.9 & 1.1 \\
Extractives & 5.4 & 6.0 \\
Dichloromethane & 0.5 & 0.8 \\
Ethanol & 2.8 & 3.9 \\
Water & 2.1 & 1.2 \\
Lignin & 10.6 & 17.8 \\
Klason & 6.9 & 14.0 \\
Soluble & 3.7 & 3.7 \\
Carbohydrates & 76.0 & 74.5 \\
Rhamnose & - & 0.7 \\
Arabinose & 0.9 & 1.7 \\
Xylose & 24.4 & 29.2 \\
Mannose & 1.0 & 1.0 \\
Galactose & 0.8 & 1.4 \\
Glucose & 48.9 & 40.5 \\
Holocellulose & 77.5 & 72.8 \\
a-Cellulose & 55.2 & 46.8 \\
\hline
\end{tabular}


(a)

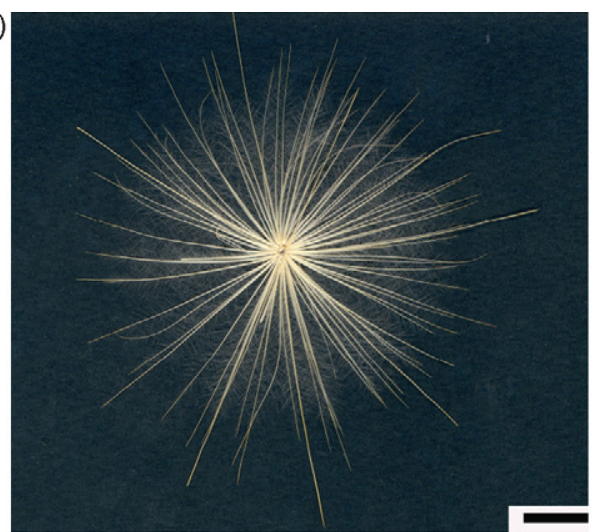

(b)

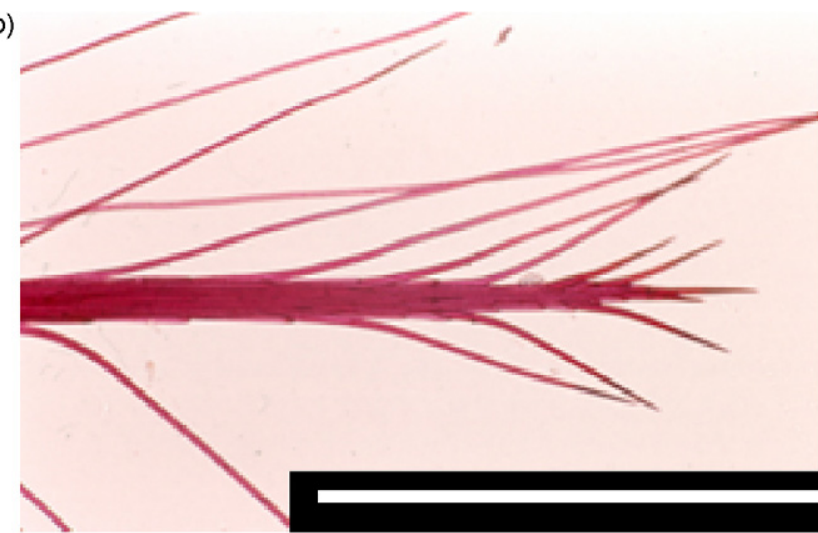

(c)

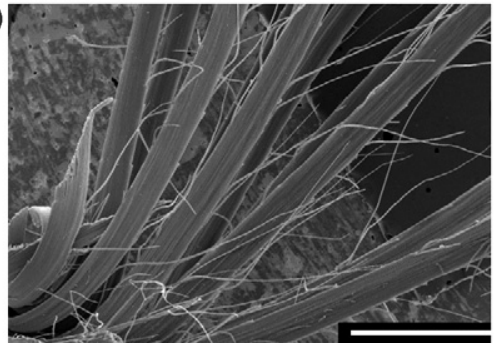

(d)
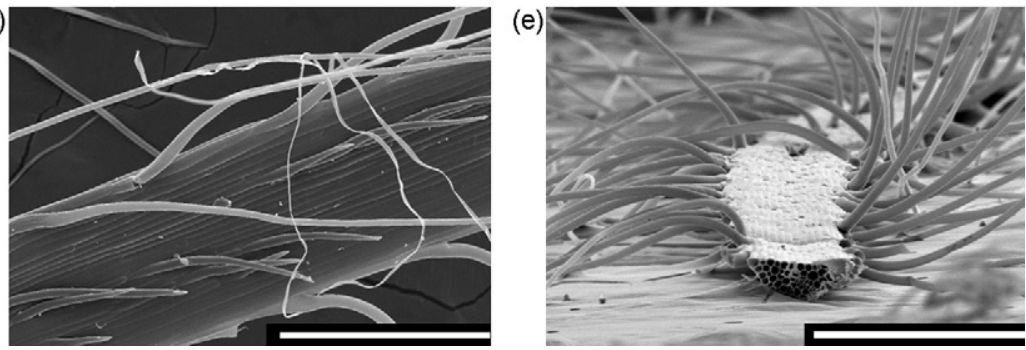

Fig. 6 - General aspect from one pappus (a). Photo obtained in an optical microscope from the top of one row of pappus with plumose filaments (250x magnification) (b). SEM images showing details of pappus: base with several rows (c), middle of one row, showing several plumose filaments (d) and transverse section of a brooked row, also with plumose filaments (e). $(-)$ Scale bar in (a) $1 \mathrm{~cm}$, (b and c) $1 \mathrm{~mm}$, and (d and e) $300 \mu \mathrm{m}$.

for paper, which show a fibre length of $0.9-1.0 \mathrm{~mm}$ and $6.1 \mu \mathrm{m}$ wall thickness (Miranda et al., 2001, 2003; Quilhó et al., 2006).

\subsection{Chemical composition}

The results obtained for the chemical analysis of the hairs and pappi are summarized in Table 2. Hairs and pappi are chemically rather similar. Ash content is low and extractives represent on average $5.7 \%$ of the material, mainly polar compounds that are soluble in ethanol and water. Lignin content is low, although higher in pappi (17.8\% vs. $10.6 \%$ ) and holocellulose content is high (77.5\% and $72.8 \%)$. The hemicelluloses are mostly made up of xylan, as shown by the sugar composition after total hydrolysis, with xylose as the main hemicellulosic monosaccharide and only minor amounts of mannose, galac- tose and arabinose, each representing on average $1 \%$ of the material. Pappi contained more hemicelluloses than hairs, e.g. xylose amounted to $29.2 \%$ and $24.4 \%$, respectively, and less $\alpha$-cellulose (46.8\% vs. $55.2 \%$ ). Correspondingly the xylose-toglucose ratios were 0.50 for hairs and 0.72 for pappi.

From a chemical point of view the analysis of the pulping quality of hairs and pappi shows favourable aspects, namely the low ash, extractives and lignin content, and the high holocellulose and $\alpha$-cellulose contents. The ash content in hairs and pappi is much lower when compared with other aerial biomass fractions from Cynara, namely the values ranging 5.4\% and $8.0 \%$ reported for stalks (Antunes et al., 2000; Gominho et al., 2001). Cynara stalks have also substantially more extractives from $14.6 \%$ to $31.8 \%$ (Pereira et al., 1994; Antunes et al., 2000; Gominho et al., 2001; Ye et al., 2005).
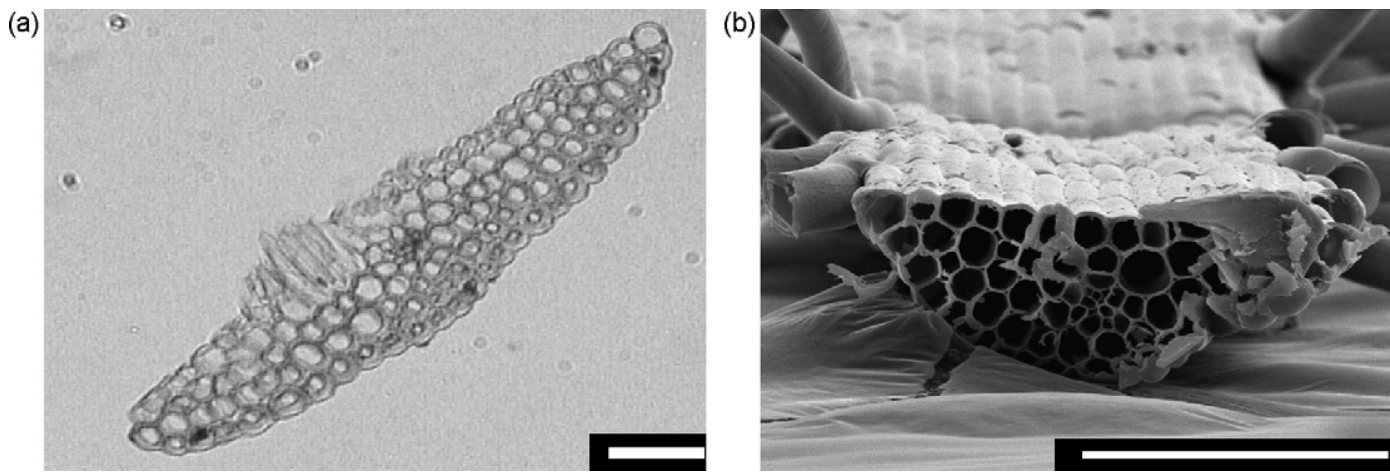

Fig. 7 - Transverse sections of C. cardunculus L. pappus row: observed in optical microscopy with 250x magnification (a) and in scanning electron microscopy (SEM) (b). (-) Scale bar in (a) $30 \mu \mathrm{m}$ and (b) $100 \mu \mathrm{m}$. 
Table 3 - Characteristics of unbleached kraft pulps made with hairs, pappi and their 1:1 mixture, obtained with different alkali charge

\begin{tabular}{|c|c|c|c|c|c|c|}
\hline Pulp & $\begin{array}{l}\text { Active alkali } \\
\left(\% \text { as } \mathrm{Na}_{2} \mathrm{O}\right)\end{array}$ & Yield (\%) & $\begin{array}{l}\text { Kappa } \\
\text { number }\end{array}$ & HexA ( $\mu \mathrm{molg}^{-1}$ pulp) & $\begin{array}{l}\text { Intrinsic viscosity } \\
\qquad\left(\mathrm{mL} \mathrm{g}^{-1}\right)\end{array}$ & $\mathrm{DP}^{0.85}$ \\
\hline \multirow{3}{*}{ Hairs } & 15 & 63 & 7 & 24.1 & 1069 & 1176 \\
\hline & 20 & 59 & 8 & 62.1 & 933 & 1027 \\
\hline & 25 & 57 & 6 & 57.0 & 856 & 941 \\
\hline \multirow{3}{*}{ Pappi } & 15 & 53 & 38 & 35.7 & 942 & 1036 \\
\hline & 20 & 48 & 11 & 46.9 & 887 & 976 \\
\hline & 25 & 45 & 11 & 31.9 & 882 & 971 \\
\hline \multirow{3}{*}{ Mixture } & 15 & 59 & 13 & 45.9 & 1102 & 1212 \\
\hline & 20 & 53 & 7 & 43.5 & 1008 & 1109 \\
\hline & 25 & 49 & 7 & 22.8 & 808 & 889 \\
\hline
\end{tabular}

As regards lignin, pappi showed more Klason lignin than hairs $(14.0 \%$ vs. $6.9 \%)$ but both are below the values of $17 \%$ reported for Klason lignin in stalks by Pereira et al. (1994) and Gominho et al. (2001). The values compare favourably to other non-wood crops like kenaf (13.2-15.0\%), cotton stalks (16.0\%), wheat straw (17.0\%), reed $(19.3 \%)$, grass $(17.7-24.0 \%)$, bamboo (23.0\%) and miscanthus (28.0\%) (Ververis et al., 2004; Madakadze et al., 1999; Shatalov and Pereira, 2002; Touzinsky, 1987) or eucalypt wood (21\%) (Pereira, 1988; Miranda et al., 2003).

The cellulose content in hairs and pappi was high with $55.2 \%$ and $46.8 \%$ of $\alpha$-cellulose compared to wood with an average $45.4 \%$ for hardwood and $43.7 \%$ for softwood (Rowell et al., 2005) and to the following non-wood crops: reed (31.1-34.4\%), wheat straw (38.2\%), miscanthus (41.5\%), kenaf (37.4-42.2\%) (Ververis et al., 2004; Deniz et al., 2004; Shatalov and Pereira, 2002; Madakadze et al., 1999; Touzinsky, 1987).

The hemicelluloses to cellulose ratio of hairs and pappi is about 1:2 which is similar to other non-wood species used in the pulp industry. This ratio is significant for their pulping aptitude considering the importance of the hemicelluloses in sheet formation during papermaking.

\subsection{Pulping and pulp properties}

Well-delignified pulps could be obtained using hairs and pappi, or their mixture, as raw materials. For instance, with $20 \%$ active alkali pulps were obtained with yields of $59 \%$ and

Table 4 - Biometric properties of unbleached kraft pulps made with hairs and pappi ( $20 \%$ alkali charge)

\begin{tabular}{lcc} 
Average characteristics & Hairs & Pappi \\
\hline Fibres (million/g) & 39.7 & 60.0 \\
Length (mm) & & \\
$\quad$ Arithmetic mean & 0.57 & 0.45 \\
Length weighted in length & 0.73 & 0.65 \\
Width ( $\mu \mathrm{m})$ & 19.3 & 16.3 \\
Coarseness (mg/m) & 0.043 & 0.033 \\
Curl (\%) & 4.2 & 4.9 \\
Broken ends (\%) & 20.4 & 15.9 \\
Fine elements $\%$ in length) & 25.0 & 37.7 \\
\hline
\end{tabular}

$48 \%$, and kappa numbers of 8 and 11, respectively, from hairs and pappi (Table 3).

No data was found for the use of hairs and pappi of any species on pulping. For Cynara, the aptitude of stalks for pulping has been studied by several researchers using kraft (Gominho et al., 2001; Gominho and Pereira, 2006), sodaanthraquinone (Abrantes et al., 2007; Antunes et al., 2000) and organosolv methods (Ligero et al., 2007). A mixture of stalks and leaves was used by Benjelloun-Mlayah et al. (1997), and the influence of pith in stalks was studied by Gominho et al. (2001), Gominho and Pereira (2006). Overall these studies considered that stalks of Cynara could be used as a raw material for pulping. However in comparison to the reported yields of $43.5-51.3 \%$, kappa number of $11-26$ and $879 \mathrm{~mL} \mathrm{~g}^{-1}$ of viscosity obtained in stalks pulps (Gominho et al., 2001; Gominho and Pereira, 2006; Benjelloun-Mlayah et al., 1997; Abrantes et al., 2007), hairs and pappi show more favourable yields and delignification (Table 3).

The variation of the alkali charge influenced differently the pulping of hairs and pappi in direct relation to their chemical composition. In the case of hairs, well-delignified pulps were already obtained at the lower alkali charge of 15\% (kappa number, 7) with substantially higher yield (63\%), higher viscosity and lower HexA content. This shows that less severe pulping conditions can be used for delignification of hairs resulting into a lower cellulose depolymerization and hemicelluloses degradation. Pappi have more lignin than hairs, and therefore they were more difficult to delignify showing a higher kappa number of 38 at 15\% alkali charge. The mixture of hairs and pappi had results in between of the individual components.

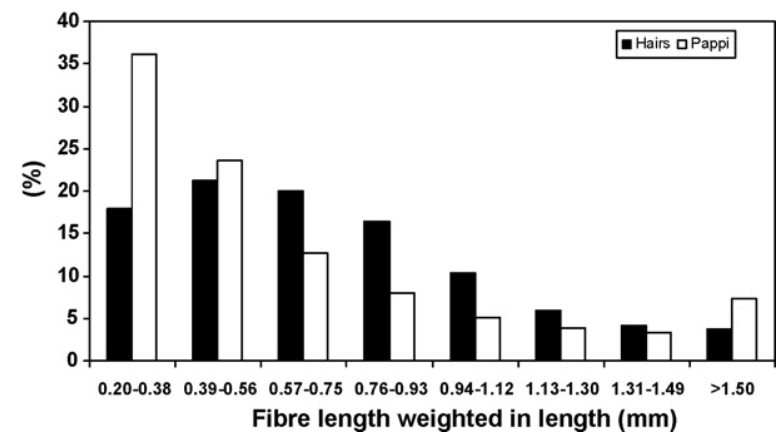

Fig. 8 - Class distribution of fibre length weighted in length for unbleached kraft pulps from hairs and pappi. 

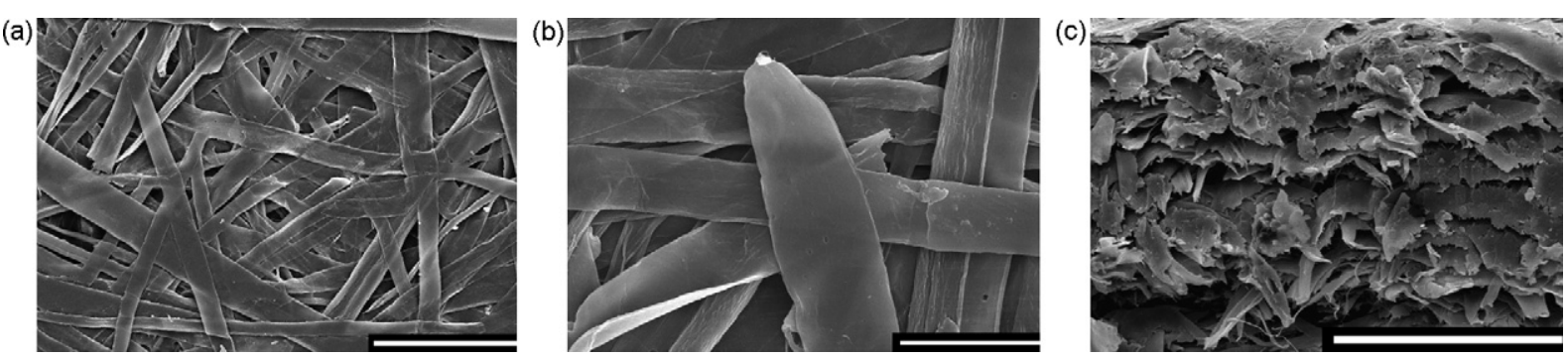

Fig. 9 - Scanning electron micrographs (SEM) of handsheet paper from unbeaten kraft pulp of C. cardunculus, from mixture of pappies and hairs. Notice the fibre collapsing and conforming at fibre-fibre intersections ( $a$ and $b$ ) and in transverse section of handsheet paper the bulk of the paper (c). (-) Scale bar, (a and c) $100 \mu \mathrm{m}$, and (b) $30 \mu \mathrm{m}$.

The dimensions of the fibre elements in the pulps of hairs and pappi (Table 4) are also related to their biometric characteristics in the original material (Table 1). Coarseness is low although somewhat higher in pulp from hairs than from pappi $\left(0.04 \mathrm{mg} \mathrm{m}^{-1}\right.$ vs. $\left.0.03 \mathrm{mg} \mathrm{m}^{-1}\right)$ as a result of their higher wall thickness. It is noteworthy that these are very low values, compared for instance with $0.12 \mathrm{mg} \mathrm{m}^{-1}$ in pulp from Cynara stalks (Gominho et al., 2001), $0.08 \mathrm{mg} \mathrm{m}^{-1}$ in cordgrass pulps (Madakadze et al., 1999) and $0.105 \mathrm{mg} \mathrm{m}^{-1}$ for eucalypt pulps (Abrantes et al., 2007). Low fibre coarseness in pulps is an indication of flexible fibres that give good surface sheet formation because of an increased bond area and denser sheets, which are qualities valued for production of printing papers (Ramezani and Nazhad, 2004). Therefore, pulps from hairs and pappi present advantages in paper formation due to their low coarseness values.

The distribution of fibre length in the pulps of hairs and pappi is shown in Fig. 8. Pulps from hairs presented higher values $(0.57 \mathrm{~mm}$ vs. $0.45 \mathrm{~mm})$ and less fine elements $(25.0 \%$ vs. $37.7 \%$, Table 4 ) than pulps from pappi. These results show that pappi cells have higher breakability which may be the result of more brittle cell walls due to the higher lignin content. The comparison of mean fibre length between pulps and the original material shows that in pulps the fibres are $42 \%$ and $25 \%$ of the intact hairs and pappi, respectively. Although it is typical in the production of pulps to have a shortening of fibres to less than half of the length during raw material preparation and delignification and depending on processing conditions, it is again noticeable that pappi were more extensively broken than hairs.

The results show that there is scope to improve the pulping process of hairs and of pappi by taking into account their chemical composition and anatomical structure. Further studies should test less intensive cooking conditions and diffusion of delignification chemicals should be improved, e.g. by steam conditioning. In such cases high yields and well-delignified pulps should be obtained with little cellulose and xylan degradation.

Fig. 9 shows the network formed by a mixture of hairs and pappi fibres after kraft pulping. It can be noticed that there is an effective interfibrilar bonding due to the conformability of the fibres (Fig. 9a and b) and that these have no pits (Fig. 9b).

The physical and optical properties of the pulps are summarised in Table 5. The handsheets made with unrefined pulps from hairs and pappi (20\% active alkali) showed promising paper making characteristics: $1.8 \mathrm{~cm}^{3} \mathrm{~g}^{-1}$ bulk, $40 \mathrm{~N} \mathrm{~m} \mathrm{~g}^{-1}$ tensile and $3.6 \mathrm{kPa} \mathrm{m}^{2} \mathrm{~g}^{-1}$ burst index for hairs and $1.4 \mathrm{~cm}^{3} \mathrm{~g}^{-1}$ bulk, $42 \mathrm{Nmg}^{-1}$ tensile and $3.4 \mathrm{kPa} \mathrm{m}^{2} \mathrm{~g}^{-1}$ burst index for pappi. The resistance of these pulps is similar to the values reported for unrefined eucalypt pulps by Wimmer et al. (2002): $57.09 \mathrm{~N} \mathrm{~m} \mathrm{~g}^{-1}$ for tensile index and $2.83 \mathrm{kPa} \mathrm{m}^{2} \mathrm{~g}^{-1}$ for burst index, although other authors report higher values for eucalypt pulps (Carvalho et al., 2000). However the full potential

\section{Table 5 - Physical and optical properties of unbleached kraft pulps made with hairs, pappi and mixture, obtained with} different alkali charge

\begin{tabular}{|c|c|c|c|c|c|c|c|c|c|}
\hline \multirow[t]{2}{*}{ Pulp } & \multirow{2}{*}{$\begin{array}{l}\text { Active alkali } \\
\left(\% \text { as } \mathrm{Na}_{2} \mathrm{O}\right)\end{array}$} & \multirow[t]{2}{*}{ Bulk $\left(\mathrm{cm}^{3} \mathrm{~g}^{-1}\right)$} & \multirow{2}{*}{$\begin{array}{l}\text { Tensile index } \\
\qquad\left(\mathrm{N} \mathrm{m} \mathrm{g}^{-1}\right)\end{array}$} & \multirow[t]{2}{*}{ Elongation (\%) } & \multirow{2}{*}{$\begin{array}{l}\text { Burst index } \\
\left(\mathrm{kPa} \mathrm{m}^{2} \mathrm{~g}^{-1}\right)\end{array}$} & \multirow{2}{*}{$\begin{array}{l}\text { Brightness } \\
\text { R457 (\%) }\end{array}$} & \multicolumn{3}{|c|}{$\mathrm{CIE}_{\text {Colour }}$} \\
\hline & & & & & & & $L^{*}$ & $a^{*}$ & $b^{*}$ \\
\hline \multirow{3}{*}{ Hairs } & 15 & 2.18 & 38 & 1.27 & 3.46 & 40 & 76 & 3 & 11 \\
\hline & 20 & 1.80 & 40 & 1.14 & 3.62 & 40 & 76 & 3 & 11 \\
\hline & 25 & 1.84 & 32 & 1.19 & 2.88 & 44 & 78 & 2 & 11 \\
\hline \multirow{3}{*}{ Pappi } & 15 & 1.87 & 18 & 0.56 & 2.04 & 24 & 64 & 6 & 14 \\
\hline & 20 & 1.37 & 42 & 0.81 & 3.40 & 32 & 70 & 4 & 13 \\
\hline & 25 & 1.26 & 31 & 0.71 & 2.79 & 27 & 67 & 5 & 13 \\
\hline \multirow{3}{*}{ Mixture } & 15 & 1.91 & 36 & 0.86 & 3.15 & 25 & 64 & 6 & 12 \\
\hline & 20 & 2.29 & 37 & 0.90 & 3.01 & 30 & 69 & 4 & 13 \\
\hline & 25 & 1.74 & 57 & 1.10 & 2.93 & 36 & 74 & 3 & 11 \\
\hline
\end{tabular}


of pulps in relation to resistance properties should only be assessed after refining.

The lower content of lignin was reflected in the optical properties of the pulps, especially in the pulp obtained with hairs that presented $41.3 \%$ for brightness and $77 ; 3 ; 11$ in $L^{*} a^{*} b^{*}$, CIELAB colour space. The brightness values obtained are comparable to those reported for grasses unbleached kraft pulp (27.9-35-5\%) by Madakadze et al. (1999).

\section{Conclusions}

In this work a detailed characterization of hairs and pappi of $C$. cardunculus capitula was made at cellular and chemical levels, which allows insight into these rather unknown plant materials.

It was also possible to demonstrate the feasibility to separate hairs and pappi as individual fractions from the capitula of $C$. cardunculus during the whole-plant fractionation. Although this fractioning might not be economically justified in most cases, these low density biomass components represent a non-negligible proportion of the whole plant ( $7 \%$ of the total biomass) and their utilization will strengthen the differentiated use of biomass fractions of the Cynara plant.

The anatomical and chemical features of hairs and pappi indicated their potential as fibre materials. They are homogeneous in terms of cell type structure, with long and slender fibres, and chemically they have low ash, extractives and lignin contents. Pulps could be produced using a conventional kraft process with high yields, low residual lignin, low coarseness values and adequate pulp properties for paper. The results also indicated that there is scope for improving pulp quality by optimising pulping conditions to this type of new raw materials. The differences between hairs and pappi may also be further exploited namely the lower lignin content of hairs and the higher slenderness and wall thickness of pappi fibres.

\section{Acknowledgements}

The authors thank Paula Duarte and Emilia Amaral from Universidade da Beira Interior (Departamento de Ciência e Tecnologia do Papel), who performed the MORPHI analyses, Teresa Quilhó and Cristiana Alves from Instituto de Investigação Científica e Tropical for suggestions regarding microscopic preparations and Isabel Baptista and Joaquina Silva for help with chemical analysis.

\section{REFERENCES}

Abrantes, S., Amaral, M.E., Costa, A.P., Duarte, A.P., 2007. Cynara cardunculus L. alkaline pulps: alternatives fibres for paper and paperboard production. Bioresour. Technol. 98, 2873-2878, doi:10.1016/j.biortech.2006.09.052.

Antunes, A., Amaral, E., Belgacem, M.N., 2000. Cynara cardunculus L.: chemical composition and soda-antraquinone cooking. Ind. Crop Prod. 12, 85-91, doi:10.1016/S0926-6690(00)00040-6.

Benjelloun-Mlayah, B., Lopez, S., Delmas, M., 1997. Oil and paper pulp from Cynara cardunculus: preliminary results. Ind. Crop Prod. 6, 233-236, doi:10.1016/S0926-6690(97)00013-7.
Browning, B.L., 1967. In: John Wiley \& Sons (Ed.), Methods of wood chemistry, vol. 2. Institute of paper chemistry. Interscience Publishers, New York, pp. 415-427.

Carvalho, M.G., Ferreira, P.J., Figueiredo, M.M., 2000. Cellulose depolymerisation and paper properties in E. globulus kraft pulps. Cellulose 7, 359-368.

Chai, X.-S., Zhu, J.Y., Li, J., 2001. A simple and rapid method to determine hexenuronic acid groups in chemical pulps. J. Pulp Paper Sci. 27 (5), 165-170.

Dalianis, C., Panoutsou, C., Dercas, N., 1996. Spanish thistle artichoke Cynara cardunculus L., under Greek conditions. In: Chartier, P., Ferrero, G.L., Henius, U.M., Hultberg, S., Sachau, J., Wiinblad, M. (Eds.), Biomass for Energy and Environment. Elsevier Sci. Ltd., Oxford, pp. 663-668.

Deniz, I., Kirci, H., Ates, S., 2004. Optimisation of wheat straw Triticum drum kraft pulping. Ind. Crop Prod. 19, 237-243, doi:10.1016/j.indcrop.2003.10.011.

Fernández, J., 1990. Lignocellulosic biomass production from annual energy crops. Report EUR 12631 EN-C. Commission of the European Communities, Luxembourg, pp. 54.

Fernández, J., 1992. Final report. Project JOUB 0030. Production and utilization of Cynara cardunculus L. biomass for energy. Paper-pulp and food industry. May 1990-August 1992. EEC. DG XII. F-4, Brussels.

Fernández, J., 1993a. Production and utilisation of Cynara cardunculus L. biomass for energy, paper-pulp and food industry. In: Grassi, G., Colina, A., Zibetta, H. (Eds.), Biomass for Energy, Industry and environment. Elsevier Applied Science Publishers, London, pp. 312-316.

Fernández, J., 1993b. Production and utilization of Cynara cardunculus L. biomass for energy, paper-pulp and food industry. Final Report JOUB 0030-ECCE. Commission of the European Communities, Brussels, p. 92.

Fernández, J., 1998. Cynara cardunculus Network. Final Report AIR CTT 921089. Commission of the European Communities. Brussels, pp. 248.

Fernández, J., Manzanares, P., 1990. Cynara cardunculus L., a new crop for oil, paper-pulp and energy. In: Proceedings of the 5th European Conference on Biomass for Energy and Industry, Elsevier Appl. Sci., London, pp. 1184-1189.

Fernández, J., Curt, D., 2004. Low-cost biodiesel from Cynara oil. In: 2nd World Conference and Exhibition on Biomass for Energy, Industry Climate Protection, Rome, Italy, May 1014.

Fernández, J., Curt, D., 2005. State of the art of Cynara cardunculus L. as an energy crop. In: Proceedings 14th. European Biomass Conference \& Exhibition. Biomass for Energy, Industry and Climate Protection, Paris, France, October 17-21.

Fernández, J., Curt, M.D., Aguado, P.L., 2006. Industrial applications of Cynara cardunculus L. for energy and other uses. Ind. Crops Prod. 24, 222-229, doi:10.1016/j.indcrop.2006.06.010.

Franco, J.A., 1984. Nova Flora de Portugal Continente e Açores, vol. II. Cambridge University Press, Lisboa.

Gominho, J., Pereira, H., 2000. An overview of the research on pulping aptitude of Cynara cardunculus L. In: Kyritsis, S., Beenackers, A.A.C.M., Helm, P., Grassi, A., Chiaramonti, D. (Eds.), Proceedings of First World Conference and Exhibition on Biomass for Energy and Industry, vol. 2. Science Publishers Ltd., UK, Sevilha, Espanha, pp. 1187-1190.

Gominho, J., Pereira, H., 2006. Influence of raw material and process variables in the kraft pulping of Cynara cardunculus L. Ind. Crop Prod. 24, 160-165, doi:10.1016/j.indcrop.2006.03.004.

Gominho, J., Fernandez, J., Pereira, H., 2001. Cynara cardunculus L. a new fibre crop for pulp and paper production. Ind. Crop Prod. 13, 1-10, doi:10.1016/S0926-6690(00)00044-3.

González, J.F., González-García, C.M., Ramiro, A., González, J., Sábio, E., Gañán, J., Rodríguez, M.A., 2004. Combustion optimization of biomass residue pellets for domestic heating 
with a mural boiler. Biomass Bioenergy 27, 145-154, doi:10.1016/j.biombioe.2004.01.004.

Karlsson, H., 2006. In: Elanders Tofters (Ed), Fibre Guide. Fibre Analysis and Process Applications in the Pulp and Paper Industry. Sweden, pp. 7-119.

Ligero, P., Villaverde, J.J., Vega, A., Bao, M., 2007. Acetosolv delignification of depithed cardoon (Cynara cardunculus) stalks. Ind. Crop Prod. 25, 294-300, doi:10.1016/j.indcrop.2006.12.009.

Madakadze, I.C., Radiotis, T., Li, J., Goel, K., Smith, D.L., 1999. Kraft pulping characteristics and pulp properties of warm season grasses. Bioresour. Technol. 69, 75-85, doi:10.1016/S0960-8524(98)00131-X.

Miranda, I., Almeida, M.H., Pereira, H., 2001. Variation of fibre biometry in different provenances of Eucalyptus globulus Labill. Appita J. 54 (3), 272-280.

Miranda, I., Tomé, M., Pereira, H., 2003. The influence of spacing on wood properties for Eucalyptus globulus Labill pulpwood. Appita J. 56 (2), 140-144.

Pereira, H., 1988. Variability in the chemical composition of plantation eucalyptus (Eucalyptus globulus Labill.). Wood Fiber Sci. 20 (1), 82-90.

Pereira, H., Miranda, I., Gominho, J., Paes, M.S., 1994. The chemical composition and raw material quality of Cynara cardunculus biomass as a pulp fibre source. In: Hall, D.O., Grassi, G., Scheer, H. (Eds.), Biomass for Energy and Industry. Ponte Press, Bochum, pp. 1133-1137.

Pires, E.F.C., Macedo, I., Esteves, C., Morgado, M., Veríssimo, P., Pereira, D., Gomes, D., 1994. Flor do cardo versus quimosina no fabrico de queijos artesanais. Química-Bol. Soc. Port. Química 54, 66-68.

Piscioneri, I., Sharma, N., Baviello, G., Orlandini, S., 2000. Promising industrial energy crop. Cynara cardunculus: a potential source for biomass production and alternative energy. Energy Conv. Manage. 41, 1091-1105, doi:10.1016/S0196-8904(99)00135-1.

Quilhó, T., Gominho, J., Pereira, H., 2004. Anatomical characterization and variability of the thristle Cynara cardunculus in view of pulping potential. IAWA J. 25 (2), 217-230.
Quilhó, T., Miranda, I., Pereira, H., 2006. Whithin-tree variation in wood fibre biometry and basic density of urograndis eucalypt hybrid (Eucalyptus grandis $\times$ E. urophylla). IAWA J. 27 (3), 243-254.

Ramezani, O., Nazhad, M.M., 2004. The effect of coarseness on paper formation. www.tappsa.co.za/archive2/APPW_2004/Title2004. Consulted in March 2008.

Rowell, R.M., Pettersen, R., Han, J.S., Rowell, J.S., Tshabalala, M.A. 2005. Cell wall chemistry. In: Rowell, R.M. (Ed.), Handbook of Wood Chemistry and Wood Composites. CRC Press, Florida, pp. 35-77.

Shatalov, A., Pereira, H., 2002. Influence of stem morphology on pulp and paper properties of Arundo donax L. reed. Ind. Crop Prod. 15, 77-83, doi:10.1016/S0926-6690(01)00098-X.

Shatalov, A., Quilhó, T., Pereira, H., 2001. Arundo donax L. reed: new perspectives for pulping and bleaching 1. Raw material characterization. Tappi J. 84 (1), 1-12.

Touzinsky, G.F., 1987. Kenaf. Pulp and paper manufacture. In: Hamilton, F., Leopold, B. (Technical Ed.), Secondary Fibres and Non-Wood Pulping, vol. 3, 3rd edition. Joint Textbook Committee of the Paper Industry. TAPPI, Atlanta, pp. 106-109.

Ververis, C., Georghiou, K., Christodoulakis, N., Santas, P., Santas, R., 2004. Fibre dimensions, lignin and cellulose content of various plant materials and their suitability for paper production. Ind. Crop Prod. 19, 245-254, doi:10.1016/j.indcrop.2003.10.006.

Villar, J., Poveda, P., Tagle, L., 1999. Obtencion de pastas al sulfato a partir del cardo (Cynara cardunculus L.). Influencia del troceado sobre la calidad de las pastas. Invest. Agr. Sist. Recur. For. 8 (2.), 305-317.

Wimmer, R., Downes, G.M., Evans, R., Rasmussen, G., French, J., 2002. Direct effects of wood characteristics on pulp and handsheet properties of Eucalyptus globulus. Holzforschung 56 (3), 244-252.

Ye, D., Montané, D., Farriol, X., 2005. Preparation and characterization of methylcellulose from annual cardoon and juvenile eucalyptus. Carbohydr. Polym. 61, 446-454, doi:10.1016/j.carbpol.2005.06.013. 